\title{
Obituary for Roger N.L. Absalom
}

\section{By Richard Bosworth}

Roger Absalom, the English-speaking world's best historian of peasant Italy, died on 9 October 2009, just short of his eightieth birthday. He was born at Bebbington in the Wirral on 28 October 1929, somewhat ironically for his future, $7^{\text {th }}$ anniversary of the Fascist March on Rome. Roger came from a sea-faring family and it was said that his initials had been chosen by his father, Roland, as the nearest possible to those of the Royal National Lifeboat Institution. Roger was a bright young boy and was educated at Calday Grange Grammar. It was a selective school proud of a history that went back to 1636 , by the Second World War having abandoned its one time exclusion of any but the sons of 'the gentlemen and yeomen' of the parish. From there, in 1949 Absalom was accepted by Christ Church, Oxford, a university that still was refreshed by a cohort of youngsters like himself and older ex-servicemen whose university life had been delayed by war.

Absalom took a degree in French and Russian and, soon after graduation and marriage, departed to Pescara, on Italy's Adriatic coast, where he taught English to the locals. His son, Daniel Szechi, now Professor of Early Modern History at Manchester University, was now born. This marriage, however, failed, and Absalom, after a stint language teaching at Lugano, returned to the UK in 1959, where, the following year, he married Patricia Folley, a librarian. While in Italy, Absalom had travelled widely across what was still a deeply peasant country and developed a love of the ordinary people whom he met, as well as a dislike for the pomposities and lies of Fascists and ex-Fascists who, in many a city, still in practice dominated the elites and set the tone of 1950s' Italy. It was as though Absalom was himself becoming a historian of modern Italy 'from the bottom up', as much instructed by human contact as by book learning. His Italy was making him.

In England, Absalom, from 1960 to 1973, pursued an academic career at the Cambridge College of Arts and Technology (CCAT), nowadays the Anglia Ruskin University (to celebrate the fact that John Ruskin opened the foundation organisation, the Cambridge School of Arts, in 1858). Working in close association with his friend and mentor, Robert G. Murray, Absalom fostered the creation of a joint department of languages and history that may have been enlivened for a time by the presence in their number of the satirical novelist, Tom Sharpe. Together Absalom and Murray persuaded the Council for National Academic Awards to approve an honours level course in history and languages, as well as semester-long placement of undergraduates at Cagliari, Pavia and Pisa universities in Italy and others of the same high quality in other countries. These developments helped pave the way for CCAT to its own university status. Soon, too, Absalom began his publishing in what was to him his new discipline with two short books, 
Mussolini and the rise of Italian fascism (Methuen, 1969) and France 1968: the May 1968 events (Longmans, 1970).

In 1973 Absalom transferred his life north to Sheffield where, four years earlier, the Sheffield Polytechnic had united and amplified some teaching institutions in the city in a process that would culminate in the title Sheffield Hallam University in 1992. With his long leather coat and Russian 'ushanka' hat, the new Head of Department and later Dean of Humanities was rumoured to drink real, that is 'Italian', coffee and was a striking figure in his new surrounds, whether occupied in lecturing, administration or in furthering his new broadly cultural and so pioneering approaches to language teaching.

Absalom retired from formal work at Sheffield in 1989, although he retained the title of, and remained an active, Honorary Research Fellow in the History group there until his death. Between 1989 and 1993 he occupied a number of administrative roles in the educational structures of the European Union, where his linguistic breadth must have been exemplary and where his work for the Erasmus and Tempus programmes continued his long-term project better to link British and European universities. However, already in the first half of the 1980s, it is possible to trace a decisive drift in Absalom's intellectual interests away from language teaching towards historical research and writing. Now his cv was showing a steady list of important articles, generally published in the leading Italian journals, Italia contemporanea, Passato e presente, Farestoria, Rivista di storia contemporanea, Il Ponte and others. The work had a double focus in a scholarly quest that Absalom would pursue until his death. One was on the story of Allied soldiery in the Italy of the Second World War. What had these soldiers done, he asked, with rigour and humanity, and what had the doing, and its Italian context, done to them? The second sector of life to attract Absalom's attention was the world of the Italian peasantry. What, he demanded, had 'liberation' done to them and they to it? What did resistance and anti-fascism mean in these little but powerful worlds of family and locality? What had Italian fascism and indeed the Roman Church and national government entailed for their reluctant consumers, as it were, and how did these 'Italian' matters fit into an Anglo-Saxon world?

Absalom gave his answers in a series of carefully composed documentary collections - Gli Alleati e la ricostruzione in Toscana (1944-45): documenti anglo-americani 2 vols, (Olschki, 1988-2001), Perugia liberata. Documenti anglo-americani sull'occupazione alleata di Perugia 1944-1945 (Olschki, 2001) and a further unpublished collection presented to the regional government of the Marche in 2004. Eventually this research would be further framed in a photographic collection that was exhibited in Turin and other Italian cities and can be viewed through its catalogue: Chiaroscuro: $i$ volti della liberazione 1943-1948 (eds. R. Absalom and C. Jefferson-Davies) (Istituto piemontese per la storia della Resistenza and della società contemporanea, 2006). There was a similar exhibition, 'Chiaroscuri della Liberazione: Volti di Donne e Bambini', staged at Palazzo Sorbello by the Uguccione Ranieri di Sorbello Foundation, Perugia. In these years, Absalom also wrote a useful brief general history of modern Italy under the title Italy since 1800: a nation in the balance? (Longman, 1995).

Absalom's masterpiece, and the term is not used lightly, was, however, his monograph, A strange alliance: aspects of escape and survival in Italy 1943-45 (Olschki, 1991). It remains paradoxical that this work was published in English by the well-known Florentine house, when more sales and recognition could have come from a major English or American university press. For some years, the book's impact may have been less than its merit 
deserved. Nonetheless, it continued to win appreciative readers and, by now, is widely accepted as one of the most significant analyses of Italy's war. An Italian translation will be published by Pendragon in Bologna in 2010.

Patricia Absalom died of cancer in 1994 but Roger went on living in the Mill at Edale where they had made a comfortable and hospitable home. There, from 2000, he became the partner of the former $\mathrm{BBC}$ producer Carol Jefferson-Davies and they were soon working busily together on a number of projects. In 2006 they would fully unite their lives by moving together to 'Coachmans' near Chirnside in the Scottish borders. Both from Edale and at his new residence, Absalom, in a stream of chapters, articles and public lectures, continued his deft and meticulous portrayal of a peasant world that, in Berlusconi's Italy, was indeed definitively lost. He did so both to professional colleagues and to the more general public, notably in Italy. He also found time to collaborate with the distinguished Tuscan economist, Giacomo Becattini (born 1927), as translator and intellectual discussant. Finally, in a life that was growing ever busier, he began work on the story of SOE in Italy, making another of his exhaustive trawls through archives in many places; he would indeed die with the harness of a historian on his back, as well as with a fuller sense that Scotland was 'home' compared with anywhere else that he had loved. In his researches in these recent years, there was fruitful collaboration with David Stafford of Edinburgh and Stafford's history of SOE, due for publication in 2010, will be dedicated to Absalom's memory.

In Italy, Absalom had long been accepted as a major historian, the senior foreign figure involved in the tardy and uneasy attempt to carry the history of the resistance beyond the 'myth of anti-fascism', with its simple binary opposition of good people and wicked fascists, towards some more nuanced and credible understanding of life in wartime. This process, certainly for Absalom, did not involve any relativising of the cruelty, the corruption and the cowardice of the dictatorship nor of a tough-minded assertion of its lingering and destructive legacy on the Italian republic. At times, some Italian historians found the Englishman formidably scathing of their efforts to avoid civil responsibility for the horrors of Fascism and the back-sliding of their Republican 'democracy'. Yet, at least outside those circles subject to 'Berlusconisation', there was widespread acknowledgement that the seemingly ageless man was both patently humane and brilliantly perceptive in reviewing the dangerous months of 1943-5. Indeed perhaps because of his origins as a linguist and perhaps because he remained always an 'archive rat', a working historian exploring Italy in Italy, Absalom in quite a few senses should be viewed as much an Italian historian of Italy as an 'Anglo-Saxon' one.

Yet, in the smaller arena of English-speaking historians of modern Italy, Absalom had won considerable presence. One reason was simple; no-one knew as much about peasants as he did. Except for those who clung to 'old fashioned diplomatic history' or other variants of top people's history, there was the necessary recognition that Italy could scarcely be understood without a serious attempt to enter its rural and regional world. In order to map that journey for us, Absalom was the best Virgil we could find. The lands that would be reached by Allied escapers after 8 September 1943 were he told us, crowded, varied and complex. Italian peasants, contrary to the enormous condescension of Marx, bore no relation to potatoes in a sack of potatoes. They were, we learned, poor but generous, local in their deepest mindsets and also somehow universal, cannily humane. They 'possessed a traditional technique of survival through concealment and displacement, and a framework of values tending to legitimate such behaviour'. They were not well 
typified by such pompous terms as Fascist or Antifascist, but rather clung to their 'commonsense' as a guide, reflecting their 'long history of exploitation and more or less successful resistance to it'. All in all, Absalom concluded, in characteristic and memorable phrases, 'there was nothing in the least like an organized Resistance movement' in those areas which safeguarded and hoped to utilise escaped soldiers (as well as displaced Germans) in 1943-4. 'There was no need for one. The peasants were, as they always had been, a Resistance Movement by tradition and by instinct'.

This statement will also do as the summary of Roger Absalom's own character and purpose as a historian and intellectual. His life began with Fascism (as he was reminded every birthday) and then had to endure the lies and hypocrisy of Thatcherism and the market and of its New Labour heirs and successors in the UK, as well as having to observe first the Christian Democrats and then their far worse replacements in Italy. Absalom stubbornly, humorously and courteously set his own path through life and his vocation as a historian. In its course, he survived, endured and produced. He never grovelled. He was proof that, among those of us who live by the word and also beyond, there is, always has been and always will be a 'Resistance movement' and this determination not to kowtow is how the humanity of humankind best passes on the torch of life.

The Editors would like to acknowledge the support Roger Absalom gave to Modern Italy, particularly in the shape of his consistent contributions to the reviews section of the journal. We are pleased to be able to publish two of Roger's reviews in this issue. 